\title{
Estimation of genetic parameters in the European black poplar (Populus nigra L.). Consequence on the breeding strategy
}

\author{
Ch. PICHOT, E. TEISSIER du CROS * \\ Ets Gautier, B.P. 1, F 13630 Eyragues \\ * INRA, Station d'Amélioration des Arbres forestiers, \\ Centre de Recherches d'Orléans, Ardon, F 45160 Olivet
}

\begin{abstract}
Résumé
Estimation des paramètres génétiques chez le peuplier noir européen (Populus nigra L.). Conséquence pour la stratégie d'amélioration
\end{abstract}

Les peupliers sont une essence hautement productive et largement répandue en France. Le programme d'amélioration pour le court et long terme doit tenir compte des caractéristiques biologiques et génétiques des espèces et des besoins économiques. Ce programme est basé sur trois espèces. Deux sont nord-américaines, un peuplier noir, Populus deltoides et un peuplier baumier, $P$. trichocarpa, la troisième est le peuplier noir européen, $P$. nigra. La présente étude se propose d'apporter des informations génétiques sur $P$. nigra en vue de les inclure dans le choix de la stratégie d'amélionation.

A l'estimation de paramètres génétiques dans des dispositifs de comparaison de clones ou de descendances maternelles issues de pollinisation libre, nous avons préféré celle obtenue grâce à un croisement factoriel complet (tabl. 2) avec des parents choisis dans différents sites français (tabl. 1) et rassemblés à la fin des années 1940 dans le Populetum de Vineuil, Loir-et-Cher, France. Les croisements, réalisés de 1973 à 1976, ont donné naissance à un dispositif de pépinière (Orléans, France) installé en 1977 et observé en 1977 et 1978. Ce dispositif avait la particularité de rassembler en un même lieu des copics des parents et les descendants, à un âge physiologique proche. Ce dispositif comprenait 10 répétitions complètes, incluant, pour chacune, 1 copie des 10 parents et 3 semis des 21 descendances obtenues. Les observations ont porté sur des caractères phénologiques, la croissance en hauteur et en diamètre, la résistance à la rouille foliaire à Melampsora larici-populina et l'angle des branches. L'analyse statistique porte sur les parents (clones) et les descendances. Elle permet d'apprécier la variabilité des caractères, leurs héritabilités et les corrélations génétiques.

L’une des questions posées à cette étude était de connaitre sa représentativité. En effet. sachant que les parents avaient été sélectionnés pour leur vigueur et sans doute pour la rectitude de leur fût. il était important d’apprécier leur variabilité résiduelle avant d'étudier celle de leurs descendants et de déterminer la validité des estimateurs. Chez les parents (tabl. 3) ce sont principalement les caractères phénologiques (débourrement, arrêt de croissance ct chute des feuilles), de même que langle des branches et la sensibilité à la rouille en 1978, qui présentent la plus forte variabilité et corrélativement la plus forte héritabilité au sens large (tabl. 4). Les caractères de croissance, par contre, ne présentent qu'une faible variabilité. Ceci peut être dù aux effets de la sélection.

La variabilité entre descendances (tabl. 3) cst d'ordre additif pour le débourrement, l'arrêt de croissance et la chute des feuilles en 1978. elle est soumise à la dominance pour l'arrét de croissance et la chute des feuilles en 1977. Un autre biais dans l'échantillonnage des parents apparaît avec langle des branches des descendants. Langle moyen des pères est beaucoup plus variable (de 30 à $55^{\prime \prime}$ ) que celui des mères (de $37^{\circ}$ à $44^{\prime \prime}$ ). Il en résulte que les descendances 
paternelles sont beaucoup plus variables que les descendances maternelles. Les héritabilités au sens strict ont ćté estimées dans les descendances et grâce aux covariances parents/descendants (tabl. 4). On retrouve des valeurs élevées pour les caractères phénologiques et pour l’angle des branches.

Les corrélations génétiques entre caractères, bien que souvent élevées, sont rarement significatives (tabl. 5). Néanmoins, une corrélation favorable apparaît, dans les descendances, cntre une vigueur élevéc et une chute tardive des feuilles. Par ailleurs, une liaison parent/enfant positive est à signaler entre hauteur à 2 ans et angle élevé des branches.

La discussion porte d'abord sur la valeur des paramètres estimés dans notre étude par rapport aux données de la littérature. Le fort déterminisme génétique des caractères phénologiques y est conforme. Il permet d'allonger la saison de végétation par voie génétique et, en conséquence, d'augmenter la vigucur. En effet. $P$. nigra ne court pas de risque de sensibilité aux gelées d'automne et de printemps. La faible variabilité clonale pour les caractères de vigueur n'est pas conforme aux autres informations de la littérature. Il faut l'attribuer peut-être à la sélection préalable qui a tronqué cette variabilité. L'angle des branches, très héritable au scens large, l'est aussi au sens strict ; l'amélioration pour ce caractère sera donc possible à la fois par sélection clonale et par sélection parentale. La tolérance à la rouille foliaire à Melampsora larici-populina est un caractère variable mais peu héritable. Seule la sélection clonale aura donc un effet. Les corrélations génétiques additives entré caractères, lorsqu'elles sont significatives ne présentent pas d'effet antagonistes. Pour sélectionner sur la vigueur. on choisira des descendances à chute des feuilles tardives. Cette sélection. si elle est faite chez les parents, entraincra un gain sur l’angle des branches des descendants.

La deuxième partie de la discussion porte sur le choix d'une stratégie d'amélioration. II est suggéré de commencer simultanément et rapidement deux voies d'améliorations. La première est pour le court terme. Elle consiste en la simple sélection phénotypique d'individus présentant le maximum de caractéristiques favorables, et leur utilisation dans des croisements interspécifiques. La seconde est pour le long terme (20 à 30 ans). Elle consiste en une ou plusieurs générations d'hybridation intraspécifique avec des clones d'origine géographique éloignée, précédant l'hybridation interspécifique. Elle devrait avoir pour effet d'augmenter l'hétérozygotie intraspécifique et, de ce fait, la plasticité de l'espèce. Elle doit aussi inclure la sélection par lignées destinée à purger les populations d'amélioration de gènes indésirables. Chaque lignée pourrait avoir une caractéristique propre, comme un débourrement précoce ou un arrêt de croissance tardif ou encore, un angle des branches élevé. Cette phase intraspécifique, précédant l'hybridation interspécifique, quelle que soit le schéma retenu, suppose une démarche analogue et parallèle pour les autres espèces incluses dans le programme d'amélioration des peupliers. Cette démarche est déjà bien avancée. Pour Populus trichocarpa et $P$. deltoïdes, les ressources génétiques sont maintenant rassemblées. Des estimations de paramètres génétiques pour $P$. deltoïdes seront prochainement publiées.

Mots clés: Populus nigra, héritabilité, corrélation génétique, débourrement végétatif, croissance, résistance rouille.

\section{Summary}

Poplars bred for the future by INRA will include two north American species : eastern and black cottonwood, and the European black poplar. Breeding strategies, now in discussion, need to be based on the genetic and economic properties of the species. The present study aims to estimate the genetic parameters in the European black poplar, Populus nigra. A factorial crossing design involving 4 female and 6 male parents was carried out between 1973 and 1976. Observations on copies of the parents and on their siblings were made in 1977 and 1978 in the experimental nursery of INRA near Orléans, France. Observations concerned phenology, growth, rust resistance and branch angle. Results showed that parents were variable for phenologic traits, branch angle and rust resistance, in 1978. In progenies, phenologic traits showed additive variability for bud burst, growth termination and leaf fall, in 1978, and dominance variability for growth termination and leaf fall, in 1977. Inheritance of these traits was estimated in parent clones, in progenics and through parent/offspring covariance. High and significant values were found for phenologic traits and for branch angle. Correlations between traits show that late leaf fall increases height growth. These results are discussed and confronted with literature. Finally a short, medium and long term breeding strategy for $P$. nigra is proposed. It includes gene collection and conservation, mating of geographically remote provenances as well as line breeding.

Key words : Populus nigra, heritability, genetic correlation, bud break, height growth, rust resistance. 


\section{Introduction}

Poplar is widely planted in France (200 000 hectares) to produce timber, plywood and pulp. Its production ( 2400000 cubic meters a year) is roughly 8 percent of the French total wood harvest. Planting areas are mostly river banks and other lowland sites.

Traits of importance to poplar growers are connected to the biology of poplars and their use. Therefore selection criteria concern :

- capacity for vegetative propagation of hardwood cuttings,

- vigour and length of growing season,

- resistance to diseases,

- form, including bole straightness, branching angle and branch diameter,

- wood density.

Most cultivars used in poplar culture are $P$. euramericana hybrids. But, in many European countries, the number of clones available for trade is very low (TeIssiER DU Cros, 1984). In France, at the beginning of the 1980s more than three quarters of the poplars produced by nurseries used to belong to 2 clones : «I 214 » and « Robusta». The hazards associated with such a narrow genetic basis are obvious. One dramatic example occurred in Northern Italy in the $1960 \mathrm{~s}$ with the outbreak of the fungal leaf spot, Marssonina brunnea. The clone I 214 had been used in the majority of plantations in the Po basin. It turned out to be rather susceptible to the disease. As a result, production dropped by more than 30 per cent. Therefore poplar breeders and pathologists concentrated on providing poplar growers with a permanently renewable set of clones with a large genetic basis.

As in most poplar breeding programmes, INRA breeders work simultaneously on several interhybridizable species. Provenance collections and tests are under way with Populus nigra, the only European black poplar, $P$. deltoildes and $P$. trichocarpa. Among the types of information needed in the choice of a breeding scheme including these three poplars, the genetic parameters of each species have to be estimated. The present study aims at estimating genetic parameters in an artificial $P$. nigra population. The results will be discussed. Proposals will be made for the breeding strategy of $P$. nigra in the French poplar improvement programme.

Genetic parameters of poplars have often been estimated in trials involving clones or open pollinated progenies of trees chosen at random in natural stands, but the habitat of poplars (long linear stands along rivers) and the low representativeness of populations studied (values of estimates linked to the particularities of each sampling) have led us to propose a complementary method to estimate these parameters. Therefore a specific mating design, whose seedlings have been observed in the experimental nursery of INRA, near Orléans, France, has been carried out.

\section{Material and methods}

\subsection{Crossing design and nursery test (tables I and 2)}

A factorial crossing design with 4 females and 6 males (poplars are dioecious) was made. It took 4 years to be completed. All parents were of natural French populations. 


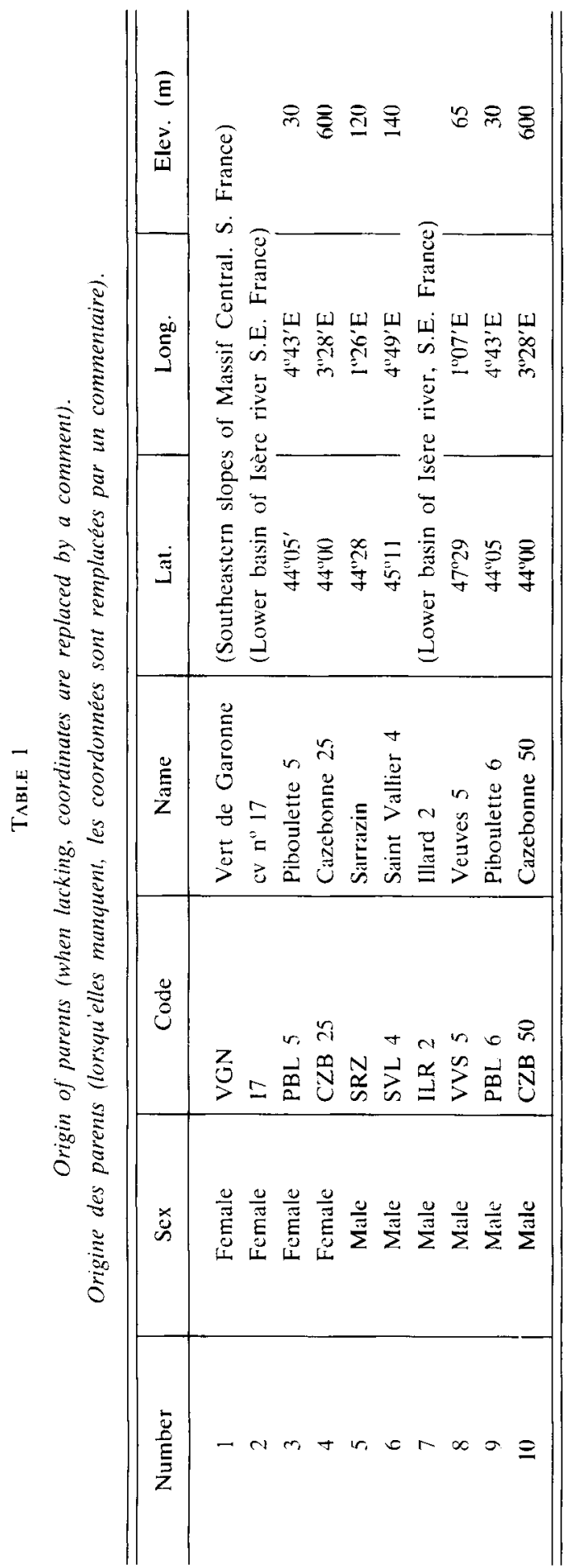


TABLE 2

Populus nigra mating design. Figures refer to years when offsprings were obtained. Croisement contrôlé de P. nigra. Années d'obtention des descendances.

\begin{tabular}{l|c|c|c|c|c|c}
\hline \hline \multicolumn{1}{c|}{ Male } & SRZ & SVL 4 & ILR 2 & VVS 5 & PBL 6 & CZB 50 \\
Female & & & & & \\
\hline VGN . . . & 1976 & 1974 & 1974 & 1976 & - & 1973 \\
$17 \ldots \ldots$ & - & - & 1975 & 1974 & 1974 & 1973 \\
PBL 5 . . . & 1974 & 1974 & 1976 & $1973-1976$ & 1976 & $1973-1975$ \\
CZB 25 . . & 1974 & 1976 & 1976 & 1975 & 1976 & 1976 \\
\hline \hline
\end{tabular}

They had been phenotypically selected for vigour and form. Form selection included bole straightness and a wide branch angle (Bouvarel, pers. comm.). The effect of this selection will be discussed. These clones had been gathered in the late 1940s in the Vineuil populetum near Blois, in the Loire river valley. Crosses were made each year in February and March with cut branches in a greenhouse.

The nursery design was laid out in Spring 1977. It included 10 complete replications of the 21 families obtained (three combinations were impossible) and vegetative copies of their parents. In each replication, each of the 21 families was represented by a plot of 3 sibs and each of the 10 parents by one copy.

Plants used to establish the trial consisted of unrooted cuttings for progenies obtained from 1973 to 1975 and of 1-year-old seedlings for progenies obtained in 1976 . This heterogeneity may have disturbed the behaviour of some progenies, particularly in the first growing season. Planting distance was $1.2 \times 0.5$ meters.

\subsection{Observations}

They consisted of :

\subsection{Phenologic traits}

Bud burst was measured at the beginning of the second growing season (1978). Nine surveys were evenly spread between April 4 and May 5. At each survey, plants having reached a particular phenologic stage (a minimum of 3 lateral buds possessing at least 3 totally spread leaves each) were considered flushed. The date when a plant was considered flushed was transformed into number of days from April 4 , then into number of degree-days (sum of daily mean temperatures over $0^{\circ} \mathrm{C}$ after February 2) which better reflects the effect of temperature on bud burst. Growth termination was measured at age 1 and 2. It is defined as a ratio : "terminal shoot elongation between August and October/annual shoot length in October $\%$. The August observation was made when all trees were still elongating (generally 3rd week of August), the October observation when elongation had stopped for all trees (first half of October). This ratio 
is highly related to growth termination. Leaf fall is the ratio of terminal shoot defoliated length on total shoot length (October $16^{\text {th }} 1977$ and 1978). seasons.

These three traits are of great importance to determine the adaptation capacity to

\subsection{Disease resistance}

$P$. nigra is fairly susceptible to Melampsora leaf rust. The nursery test was designed to increase and homogenize the level of inoculum (three rows of highly susceptible black cottonwoods where planted as border and median rows). The observations were made during the first and second growing seasons. Each leaf of a randomly chosen lateral shoot was given a mark according to the following scale : 1 : no rust ; 2 : less than 10 uredospores; 3 : less than $1 / 2$ leaf infected; 4 : between $1 / 2$ and $3 / 4$ leaf infected ; 5 : more than 3/4 leaf infected. Each tree was given a value consisting of the ratio of leaves noted 3,4 and 5 over the total number of leaves observed.

\subsection{Vigour}

Observations concerned total height at age 1 and 2 and stem diameter at $0.5 \mathrm{~m}$ height, at age 2 .

\subsection{Form}

Branch angle is of great importance in poplars because the scar surface after pruning is smaller when the branch angle is larger. It has also been noticed by TEISsIER Du CRos (1969) that the more horizontal a branch is, the thinner it tends to be (strong genetic and environmental correlations). Furthermore, we have observed a high juvenile-mature correlation for this trait. The crotch angle of 5 major branches per tree was measured in degrees. Major branches appear in the upper end of the terminal shoot of the previous growing season. The average of these 5 angles was given to each tree.

All observations concerned each ramet of the parents and each sib of the families.

\subsection{Variance analysis}

All data were processed with a multivariate variance analysis according to the following statistical models (BaCHaCou et al., 1981).

First statistical model : parent-clones :

\begin{tabular}{|c|c|c|c|c|c|c|c|c|}
\hline & $X_{i j \mathrm{k}}$ & $=$ & $\mu$ & + & $\mathrm{R}_{\mathrm{i}}$ & + & $\mathrm{C}_{\mathrm{j}}$ & + \\
\hline Factor : & General & & Mean & & Rep̧licate & & Clone & \\
\hline Effect & & & & & Fixed $(F)$ & & Random (R) & \\
\hline Variance : & $\sigma_{\mathrm{p}}^{2}$ & & & & & & $\sigma_{c}^{2}$ & \\
\hline
\end{tabular}

Second statistical model : offsprings :

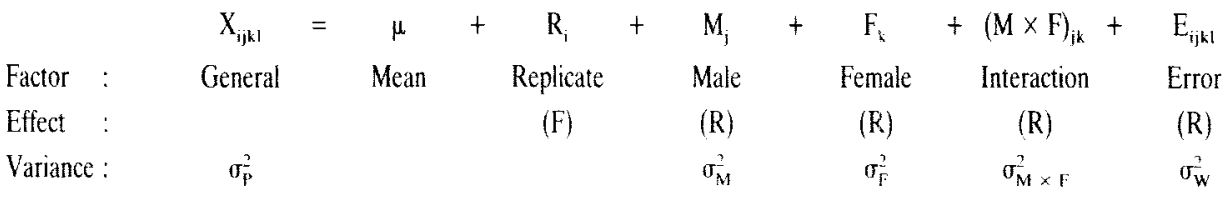


First genetic model : parent-clones :

$$
X_{i j \mathrm{k}}^{\prime}=G_{i j k}+E_{i j k}
$$

where $X_{i j k}^{\prime}=$ phenotypic value adjusted to replication effect;

$G_{i j k}=$ genotypic effect ;

$\mathrm{E}_{\mathrm{j} ; \mathrm{k}}=$ environmental effect.

Second genetic model: offsprings :

$$
X_{i j k l}^{\prime}=A_{i j k l}+D_{i j k l}+E_{i j k l}
$$

with $X^{\prime}{ }_{i j k l}=$ phenotypic value adjusted to replication effect ;

$\mathrm{A}_{\mathrm{i} \mathrm{ik} \mathrm{k}}=$ additive effect ;

$\mathrm{D}_{\mathrm{ijki}}=$ dominance effect (epistatic effect is ignored) ;

$\mathrm{E}_{\mathrm{ijkl}}=$ environmental effect.

\subsection{Estimation of genetic parameters}

The first statistical model permits the estimation of genotypic variance, broadsense heritability $h_{b s}^{2}=\sigma_{c}^{2} /\left(\sigma_{c}^{2}+\sigma_{w}^{2}\right)$ and clonal correlation. The second statistical model gives estimates of additive and dominance variance, broad sense and narrow sense heritability, combined genetic correlation. Mid-parent/full-sib covariance gives one more estimate of the narrow sense heritability.

In a factorial mating design there are 3 possibilities to estimate the additive genetic variance $\left(\sigma_{A}^{2}\right)$ :

$$
\begin{array}{rlr} 
& \sigma_{\mathrm{A}}^{2}=4 \sigma_{\mathrm{M}}^{2}(1) ; & \sigma_{\mathrm{A}}^{2}=4 \sigma_{\mathrm{F}}^{2} \quad(2) ; \\
\sigma_{\mathrm{A}}^{2}= & 4\left[(\mathrm{~m}-1) \sigma_{\mathrm{M}}^{2}+(\mathrm{f}-1)\right. & \left.\sigma_{\mathrm{F}}^{2}\right] /(\mathrm{f}+\mathrm{m}-2)
\end{array}
$$

where $\sigma_{\mathrm{M}}^{2}$ and $\sigma_{\mathrm{F}}^{2}$ respectively are the variance of the $\mathrm{m}$ half-sib families of the male parent, and of the $f$ half-sib families of the female parent. The third estimate is called the combined additive genetic variance. It is used in the estimation of the narrow sense and of the broad sense heritability (tabl. 4) calculated in the progeny test.

\section{Results}

\subsection{Trait variability (tabl. 3)}

To be general, this study should have been based on a sample of parent clones representing $P$. nigra in a given part of its range, say France. Our parent-clone sample is not representative because it is limited to 10 clones and because it results from phenotypic selection. Anyhow, it is now important to determine how representative it can be and how much variability remains after selection.

\subsection{Genotypic variability between parent-clones}

Column 1 of table 3 gives the percentage of clonal variance in the total variance for the 10 parent-clone sample. Phenologic traits (bud burst, growth termination and leaf fall) showed significant variability. This variability seemed greater in year 2 than in year 1 . Among growth traits, only height at age 2 was variable at 1 percent level. When compared with height at age 1 , the significance was due to an increase of the clonal variance. Branch angle varied between 30 degrees (for male-parent CZB 50) and 55 degrees (for male-parent VVS 5) with a core of clones between 37 and 44 degrees 


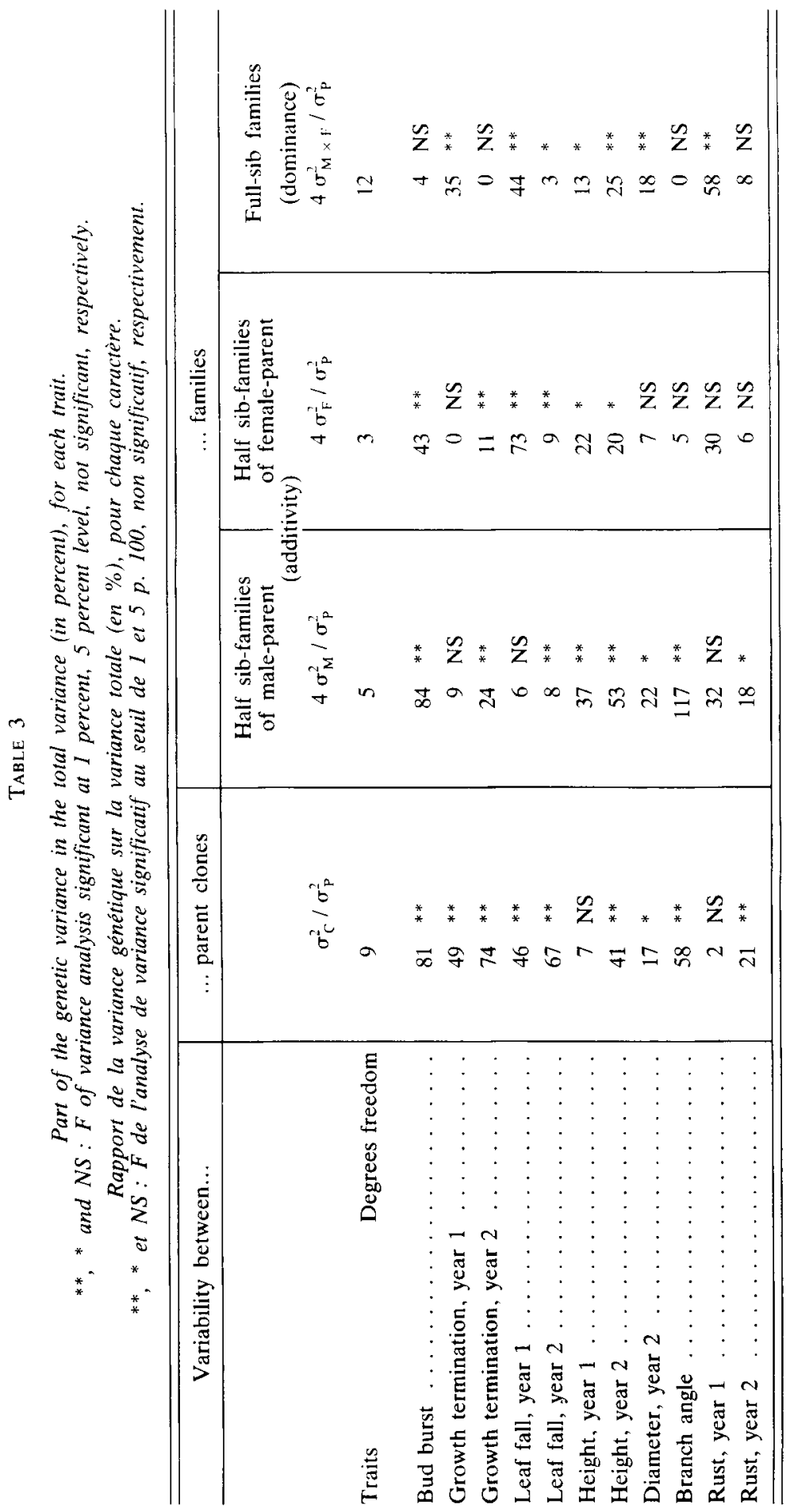


for all others, including all 4 female-parents. Rust outbreak showed significant variability only in year 2 . When compared with year 1 , this increase of variability is mostly linked to a greater homogeneity within the trial (lower replicate and error effect) which may have resulted from an increased level of inoculum. Clones VVS 5 and SRZ seemed highly susceptible (more than 25 percent leaves with marks over 3 ) whereas clones PBL 5 and CZB 25 seemed rather resistant (more than 90 percent leaves with less than 10 uredospores).

In the following part of this paper, traits with low or no clonal variability will be ignored, i.e. height and rust susceptibility in year 1 and diameter in year 2 .

\subsection{Variability between families}

Column 2, 3 and 4 of table 3 give the part of additive or dominance variance in the total variance of the progeny test. Phenologic traits showed different signs of variability : additive variability for bud burst, growth termination and leaf fall in year 2 , dominance variability for growth termination and leaf fall in year 1 . Height growth in year 2 showed a more important additive effect between the male-parent half-sib families than in the female-parent half-sib families and a dominance effect. We see no particular reason why the sampling of the parents resulted in such a difference. Branch angle also showed a much stronger additive effect in the male-parent half-sib families whereas no genetic variability appeared between female-parent half-sib families. This difference must be related to the sampling bias of the parents already stressed earlier : all female-parents belonged to a central core of clones with low variability of branch angle.

\subsection{Heritabilities (tabl. 4)}

Narrow sense heritability was estimated in the progeny test, using the combined additive variance on the one hand and the mid-parent/full-sib regression on the other hand. These two estimates show a good relationship. High values are found only for phenologic traits in year 2 : bud burst, growth termination and leaf fall. Branch angle heritability although high is not significant. Lack of significance may be due to the already mentioned reduced variability between the female-parents. But an uncertainty in the significance test is more likely to be the reason.

Broad sense heritability was estimated in parent-clones. As it is an expression of the part of the genotypic variance in the total variance, the values are the same as in column 1 of table 3. Broadsense heritability was also estimated in the progeny test. High values are found for bud burst, leaf fall, height growth and branch angle. Lack of significance for branch angle broad sense heritability may also be due to a mistake.

\subsection{Correlations between traits (tabl. 5)}

The additive genetic correlation between traits has been estimated in progeny tests using combined estimations of additive variance and covariance, and from parent/halfsib covariance. Although some values are very high, only a few of them are significant at the 5 percent level. In the progeny test a high vigour is related to a late leaf fall in year 1. There is a strong and favourable parent/offspring relationship between height growth and branch angle. 


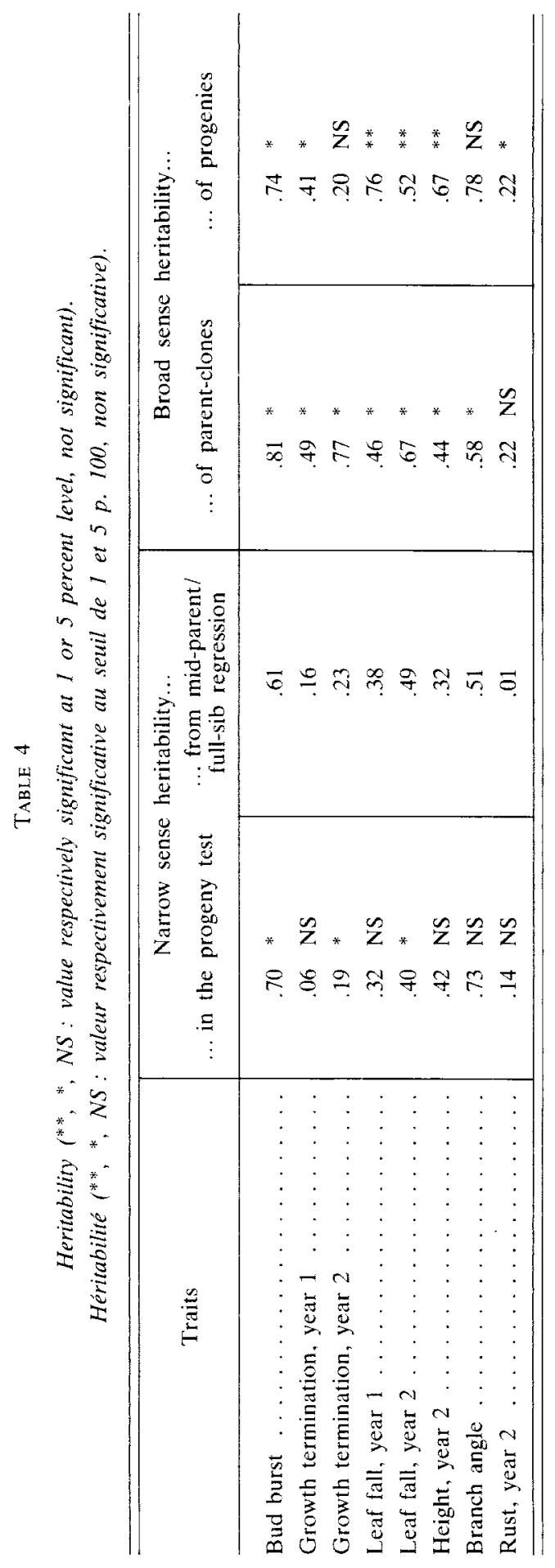




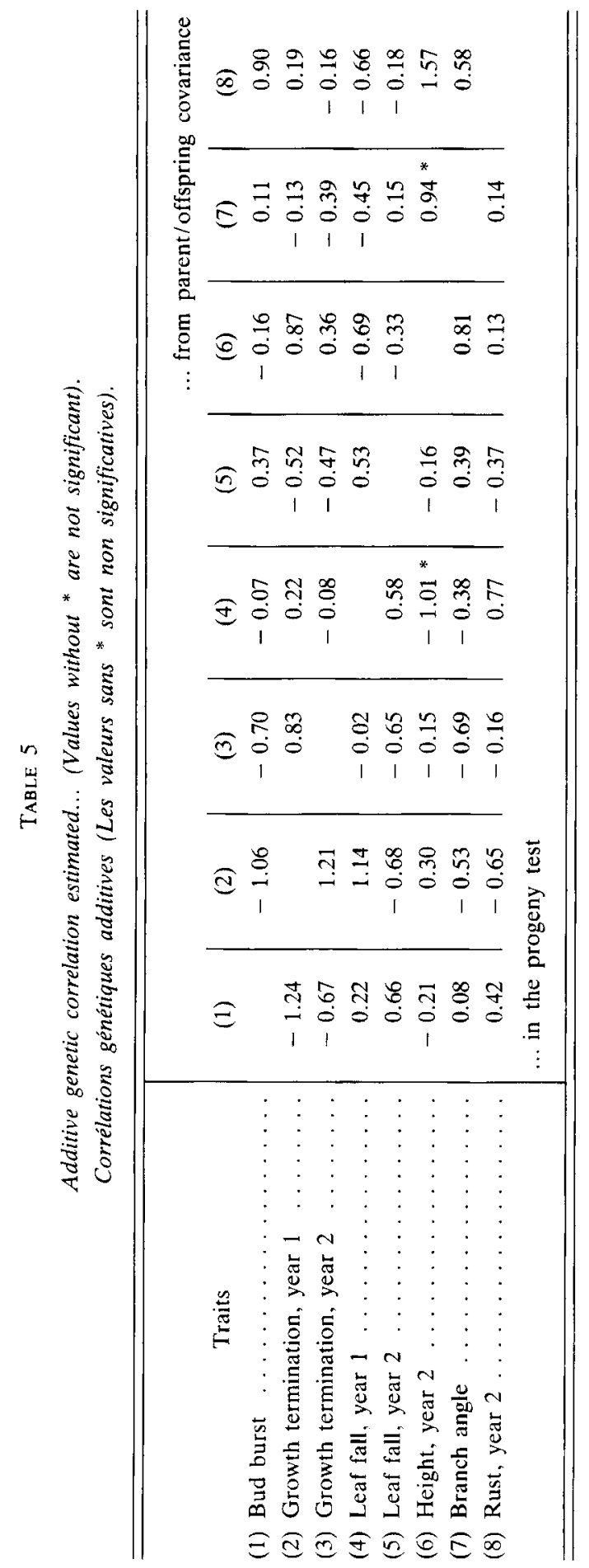




\section{Discussion}

Firstly, one should remember that this study is limited to a 4 female $\times 6$ male mating design which does not represent all the variability of Populus nigra, even in France. Therefore our information is representative of our parent sample and needs to be compared with results in the literature. Generalization and incidence on a breeding strategy will be suggested only when a good agreement between different sources of information is found. Furthermore traits were measured on one nursery trial, meaning that genotype $\times$ site interaction and juvenile-mature correlations could not be considered.

\subsection{Phenologic traits}

Bud burst, growth termination and leaf fall appear genetically variable in our Populus nigra parent and progeny test. This agrees well with our previous results on $P$. nigra open pollinated progenies from natural stands (TEISsIER DU CROs, 1977) and with PANETsos results (1969), showing that the length of the growing season is under strong genetic control. It also matches results on Populus deltoïdes (FARMer, 1970 ; YING, 1974) and on many other species of temperate climates (WRIGHT, 1976). Populus nigra is a natural species in France. It is adapted to the local climate, and even with a slight transfer northwards, no damage by winter temperature, and spring or autumn frost has ever been mentioned. Thanks to the genetic independance of phenologic traits, the selection of early-flushing-late-growing genotypes will result in a gain of vigour for young trees.

\subsection{Growth traits}

Height and diameter growth is not very variable in our experiment. Consequently broad and narrow sense heritability is low or not significant. It is therefore quite difficult to base a selection and breeding programme on a direct use of our results on these traits and more so because our results are based on juvenile observations. Nevertheless «the heritability of diameter growth was studied by Avanzo (1971a and 1971 b) in clonal tests of several $P$. nigra cultivars. The heritability values for basal area were high $\left(\mathrm{h}^{2}=.73\right.$ to .80$)$ and indicated that substantial gains can be obtained in growth rate by intensive selection of clones " (Zsuffa, 1974). Therefore, as the selection of our 10 clones has included vigour, it may have been genotypically efficient and may have resulted in a reduction of height and diameter variability.

\subsection{Branch angle}

In spite of selection, a high level of variability remains in our 10 clone sample. Consequently the clonal broad sense heritability is significant. On the other hand the parent/offspring narrow sense heritability is amongst the highest values that we obtained. Although there remains some doubt about its significance level, the narrow sense heritability in the progeny test is very high. PoHL (1964) has found that the pyramidal form (fastigiate branches) was strongly inherited. PANETsos (1969) studying crosses between non-fastigiate, semi-fastigiate and fastigiate $P$. nigra came to a similar 
conclusion. He also observed that the crown form was determined by a small number of major genes (ZsuFfa, 1974). So branch angle appears as a trait with a strong genetic control. Furthermore selection of parents for a wide crotch angle will improve their progenies both for crotch angle and height growth, because of the significant parent/ offspring additive correlation between these two traits.

\subsection{Rust resistance}

The first growing season has permitted a good homogenization of the inoculum. In the second growing season variability of rust resistance appears clearly between parentclones and slightly between half-sib families of the male-parent. None of the heritabilities or of the additive genetic correlations are high or significant. Steenackers in 1972 had already shown the efficiency of rust clonal selection. But Zsuffa, in his literature review (1974), did not mention any work on narrow sense heritability of $P$. nigra rust resistance. An attempt in this direction was made by TeIssier DU Cros in 1977 with a sample of 21 open-pollinated progenies of $P$. nigra. His results made him think that the positive correlation he found between rust susceptibility and height growth was of genetic nature. In another poplar species, P. deltoïdes, Farmer (1970) mentioned a half-sib family heritability of .51 for Melampsora rust resistance, leading to nearly complete resistance if the best family was selected (WRIGHT, 1976), but there is an important difference between $P$. nigra and $P$. deltoïdes concerning rust resistance. In French conditions, total rust resistance of $P$. nigra is probably very rare whereas it is much more frequent in $P$. deltoides (Pinon and Teissier du Cros, 1976). These results suggest that rust resistance (or tolerance, which is now preferred by pathologists) may be obtained more easily through clonal selection than through multi-generation breeding.

\subsection{Consequence for improvement}

Poplar genetic improvement in Western Europe has long been based on interspecific hybridization, but poplar breeders now agree that a long term interspecific breeding strategy should first include intraspecific hybridization, either to combine traits existing in remote geographical parts of the range or to purge deleterious genes, before entering the interspecific stage (KANG, 1982).

Populus nigra is a good candidate to be included in the French poplar improvement scheme because of its adaptation to many environments, its fair resistance to Marssonina brunnea, its total resistance to the bacterial canker (Xanthomonas populi Ridé) and to mistletoe. Furthermore it can be easily hybridized with $P$. trichocarpa and $P$. deltoïdes.

The intraspecific stage starts with gathering a large genetic basis. In France, gene conservation started in 1971 and needs to be completed with the help of other countries in the natural range of the species. As a result of our study, in the second part of the intraspecific stage, clonal selection will concern phenologic traits, branch angle and rust tolerance. Finally multi-generation breeding will be efficient for bud burst, leaf fall and branch angle. During this intraspecific stage, line breeding will be envisaged. Each line should have an independant characteristic such as early flushing or late leaf fall or wide branch angle. Lines should be intercrossed before the interspecific stage of the breeding scheme. Line breeding appears definitely as a very long term breeding scheme but the 
sooner the decision is made to start in such a way, the sooner the programme will become economically justifiable (GULLBERG and KANG, 1985).

The interspecific stage will then follow. For the short term it will be based on a more or less empirical selection of the parents, but for the long term it will be based on a reciprocal recurrent strategy, meaning that the interspecific combining ability will be one of the main parameters to estimate. The traits included in selection will be mainly vigour, plasticity, disease resistance and wood quality, but an interspecific breeding scheme assumes that simultaneous intraspecific breeding schemes are run for the other species concerned. In France, provenance collection and gene conservation are underway with $P$. deltoides and $P$. trichocarpa. A publication by the same authors will soon bring information on genetic parameters of $P$. deltoïdes.

Reçu le 28 août 1987.
Accepté le 17 mars 1988.

\section{Acknowledgements}

We wish to thank Pr. Reinhardt Stettler, Dr. Hyun Kang, Dr. Philippe Baradat, Dr. Bernard Roman-Amat and Dr. Catherine Bastien for their very efficient help in reviewing this paper, as well as the staff of the Forest tree breeding laboratory INRA, Orléans, for its technical help in establishing the experiment, maintaining it and in making observations. We are most grateful to Patricia Montes for her patience and kindness in typing this paper.

\section{References}

Avanzo E., 1971a. Considérations préliminaires sur la sélection de nouveaux clones de peupliers de la section Aigeiros en Italie centro-méridionale. 14th Session, International Poplar Commission. FAO/CIP/71/20. 10 p.

Avanzo E., 1971b. Réussites et surfaces terrières moyennes de quelques clones de peupliers dans une pépinière de l'Italie Centrale. 14th Session, International Poplar Commission. FAO/CIP/ $71 / 21.13 \mathrm{p}$.

Bachacou J., Masson J.P., Millier C., 1981. Manuel de la programmathèque statistique Amance 1981. INRA, Champenoux, $516 \mathrm{p}$.

FARMER R.E.R., 1970. Genetic variation among open-pollinated progeny of eastern cottonwood. Silvae Genetica, 19, 149-151.

Gutlberg U., Kang H., 1985. A model for tree breeding. Studia Forestalia Suecica. $\mathrm{N}^{\circ} 169,8 \mathrm{p}$.

Kang H., 1982. Components of a tree breeding plan. Proceedings of the I.U.F.R.O. Joint Meetings of Working Parties on Genetics about Breeding Strategies including Multiclonal Varieties. Sensenstein. GFR, 119-135.

Panetsos K.P., 1969. Quality characters in Populus. 2nd World Consultation. Forest Tree Breeding. Washington D.C. Documents. Vol. I. FO-FTB-69-3/3, 285-291.

Pichot C., 1986. Estimation des paramètres génétiques chez les peupliers de la Section Aigeiros. Mémoire de Diplôme d'Agronomie Approfondie "Amélioration des plantes ». Ecole Nationale Supéricure Agronomique de Rennes. INRA Station d'Amélioration des Arbres Forestiers. Orléans, $90 \mathrm{p}$. 
Pinon J., Teissier du Cros E., 1976. Sensibilité aux rouilles de différentes espèces de peupliers. Melampsora larici-populina Kleb. et M. allii-populina Kleb. Ann. Sci. Forest., 33 (2), 49-59.

PoHL Z., 1964. Inheritance of pyramidal crown form by the hybrid progeny of Populus pyramidalis. Roz. Arboretum Korniczkie Rocznik, 9, 199-222.

SteEnaCKers V., 1972. The state of knowledge in breeding rust resistant poplars. In Biology of rust resistance in forest trees. U.S.D.A., Forest Service. Miscellaneous publications $\mathbf{n}^{\circ}$ 1221, 419-430.

TeIssier du Cros E., 1969. Evolution de l'angle d'insertion des branches de peupliers. Thèse de $3^{\mathrm{c}}$ cycle Biologie végétale. Faculté des Sciences de Clermont-Ferrand, $75 \mathrm{p}+$ annexes.

Teissier du Cros E., 1977. Aperçu de la transmission héréditaire de quelques caractères juvéniles chez Populus nigra L. Ann. Sci. Forest., 34 (4), 311-322.

Teissier du Cros E., 1984. Breeding strategies with poplars in Europe. Forest Ecology and Management, 8, 23-29.

WRIGHT J.W., 1976. Introduction to forest genetics. Academic Press. New York, San Francisco, London, $463 \mathrm{p}$.

YING C.C., 1974. Genetic variation of eastern cottonwood (Populus deltoïdes Bartr.). Neb. Agr. Exp. Sta., Dep. Forest. Prog. Rep. no 1, 148 p.

Zsuffa L., 1974. The genetics of Populus nigra L. Annales Forestales, 6 (2), 53 p. 